\title{
THE ARCHPRIEST, TROTACONVENTOS, DON MELÓN AND DOÑA ENDRINA: LOST VERSES AND MISDIRECTED SOURCES
}

\section{Carlos Hawley-Colón}

In Federica Accorsi's 2012 article "El Pamphilus de Juan Ruiz,", the author follows Luis Jenaro-MacLennan's lead and seeks to discern which manuscript of Ovid's famous play might have most directly informed Juan Ruiz in his composition of the Don Melón, Doña Endrina, Trotaconventos episode of the Libro de buen amor. Accorsi sets up her thesis as follows:

To begin, it must be said that the probability that the very manuscript used by Juan Ruiz may have been preserved is very remote, among other things because only four of the known codices indisputably derive from dates prior to the composition of the Libro. Moreover, we cannot dismiss the possibility that the poet had the opportunity to see more than one enactment of the work, perhaps at different points of his life. I do not think that the adaptation could have been made exclusively from memory, but it would not be strange that ensuing reminiscences of readings from youth should have left their footprints, constituting one more source. My objective has been to locate rather the branch to which to assign the particular manuscript of the Pamphilus known to Juan Ruiz, or at least to establish some fixed and characteristic textual locations of this manuscript source, as a starting point for future research. ${ }^{2}$

\footnotetext{
${ }^{1}$ Federica Accorsi, "El Pamphilus de Juan Ruiz." Centro Virtual Cervantes, http://cvc.cervantes.es/literatura/arcipreste_Hita/02/accorsi.htm. In her discussion Accorsi cites Luis Jenaro-MacLennan, "Sobre el texto del Pamphilus en el Libro de buen amor," Revista de Filología Española 68 (1988): 143-51.

2 "Para empezar, hay que decir que la probabilidad de que el manuscrito utilizado por Juan Ruiz se haya conservado es muy escasa, entre otras cosas porque sólo cuatro de los códices conocidos son seguramente anteriores a la composición del Libro. Además, no podemos excluir que el poeta haya tenido la oportunidad de ver más de un testimonio de la obra, tal vez en momentos distintos de su vida. No creo que la adaptación pueda haberse hecho exclusivamente de memoria, pero no sería extraño que eventuales reminiscencias de lecturas juveniles hubieran dejado sus huellas, constituyendo una fuente más. Mi objetivo ha sido, pues, el de localizar más bien la rama a la que asignar el manuscrito juanruiciano del Pamphilus, o al menos establecer unos lugares textuales fijos y característicos de esta
} 
Which version of Ovid's Pamphilus primarily informed the Archpriest's rendering of his version of the episode? What are the sources of the archpriest's rendition? Such a search does seem natural enough. A great deal of Libro scholarship follows this tradition. Much of philological erudition is invested in drawing connections between Libro de buen amor verses and their many informing underpinnings, including the Goliard poets, the fabliaux, and, of course, Ovid. And it is somewhere between Ovid and the archpriest that my study wishes to interact with and, optimistically, contribute to the colloquy concerning informing textuality and the Libro de buen amor.

The section in question is preceded, perhaps introduced, by a long conversation between the Archpriest and Don Amor (576-91) about the evils of wine and some advice for the Archpriest concerning women and wooing (549-75). It is at this point, stanza 574, that Don Amor announces that Doña Venus shall be the one to instruct Juan Ruiz further. The Gayoso manuscript relates it thusly:

mucho mas te deria si podiese sosegar mas tengo por el mundo muchos de castigar panfilo mj criado que se esta bien de vagar con mj muger doña venus te verna $\mathrm{A}_{\text {castigar }}^{3}$

And Salamanca like this:

Mucho mas te diría sy podjese aqui estar mas tengo por el mundo otros muchos de pagar pesales por mj tardança a mj pessa del vagar Castigate castigando E sabras a otros castigar

fuente manuscrita, como punto de partida para futuras investigaciones." Translation by Carlos Hawley Colón.

${ }^{3}$ All citations are from Juan Ruiz, Libro de Buen Amor. Texto sinóptico, ed. Margarita Freixas Alás (Bellaterra: Centro para la Edición de Clásicos Españoles, 2002), CD-Rom edition. All English translations are by Elisha Kent Kane, The Book of Good Love (Newark, Delaware: Juan de la Cuesta, 1933).

A great deal more on this I'd speak if I could here remain But there are other lovers in the world I must sustain Who fret as much at my delay as I fret for their pain; If now, you're wise as I advise, go help some other swain. 
These lines are followed in only the Salamanca manuscript by stanza 575:
Yo Johan Ruyz el sobredicho acipreste de hita
pero que mj coraçon de trobar non se quita
nunca falle tal dueña como a vos amor pynta
njn creo que la falle en toda esta cohyta ${ }^{4}$

Here Don Amor leaves the Archpriest to rest and reflect upon the advice he has been given. So, when the poet awakens, stanza 653, the drama comes to life, a life that will not come to an end until stanza 891.

The plot of Ovid's Pamphilus de amore, for any who are unacquainted with one or both of the two works, or even its third Spanish reincarnation, La Celestina, is a rather simple one and progresses as follows: Pamphilus falls madly in love with Galatea, and in order to pursue or indulge his passionate designs he first appeals to the goddess Venus and later seeks the aid of a resourceful old woman who mediates the love interests. As a result of the go-between's insight and ingenuity, the prospective lovers find themselves alone and Pamphilus imposes his lust over Galatea's virtue; the comedia ends amid Galatea's lamentations and the old woman's efforts to appease and apologize. In the Libro de buen amor, the Pamphilus character comes to be occupied by Don Melón/Juan Ruiz while Galatea's role is now Doña Endrina and the old woman is Trotaconventos. Venus remains Venus. The degree to which this love is mutual or unrequited may vary slightly between the Pamphilus de amore and the Libro de buen amor, but the plot is essentially identical even including the final resolution: marriage.

The poetic contributions of Ovid and Juan Ruiz, giving us Pamphilus, Don Melón, Galatea, and Doña Endrina, Anus (old woman) and Trotaconventos, offer an opportunity to explore textual evidence, both preserved and lost, of a medieval aesthetic. In the case of the Archpriest, what is preserved serves, in part, to frame some of what has been lost or, at least, what is missing from what must have been a complete version of the Libro de buen amor. And what is missing may be of some use while considering informing textuality. Hence, the question

${ }^{4}$ I, Juan Ruiz, 'foresaid Archpriest of Hita, do object

That though for love both verse and song I never did neglect,

I still have found no paragon as you, Sir Love, expect,

Nor do I think such girls exist for all our sorry sect. 
of "what exactly is missing from this section of the Libro de buen amor" leads to some inevitable points of interest. One of the most striking of the two major lacunae in this segment shows itself in the heart of the climactic moments of Don Melón and Doña Endrina's amorous adventure.

The whole of the account acts itself out between stanzas 653 and 891 but it is between stanzas 877 and 878 that the aforementioned lacuna occurs. Scholars agree that two folios, some thirty-two stanzas, have gone missing from all three remaining manuscripts: Gayoso, Toledo, and Salamanca. Since the number seems to be so unanimously agreed upon by scholars and book editors, ${ }^{6}$ one might wonder why it is that stanza 878 is not referred to as stanza 909. But indeed, that would not prove to be a viable option either. This large gap does not represent the only example of missing verses to interfere with easy reading, easy editing, or easy presentation during this adventure, nor the episodes coming before and after. The first two lines of stanza 660 are absent, the final verse of stanza 765 is also missing, and between stanzas 781 and 782 another two whole folios, another thirty-two stanzas, are nowhere to be found. That would fix our stanza count not at the 238 that can be read or performed directly

\footnotetext{
${ }^{5}$ Looking at the problem from a purely quantitative point of view, one can see that between stanzas S7 and S8 several verses are missing, perhaps an entire page, 16 cuartetos. A song (cantiga) is missing that is named in S/G81a, which should probably appear directly after cuarteto 81. S92 speaks of another cantar that could have appeared following stanza 96. S103d names a troba (song) that is missing, and 104a names cantigas that have also gone missing and, while the plural is used, no notion of how many is communicated. S170a makes reference to "trobas" and "cantares," while S171d refers to "estas cantigas" which may speak to the "trobas \& cantares" mentioned in the previous cuarteto, none to be found within the text. Again, we do not know how many have gone missing. Verses 660a and $660 \mathrm{~b}$ are missing from all manuscripts. Verse $765 \mathrm{~d}$ is missing as are the next 6 cuartetos. Thirty-two cuartetos are missing between stanzas 781 and 782 . Thirty-two more cuartetos are also missing between 877 and 878. S915a speaks of more "cantares" not to be found in the text. Several "cantares" first mentioned in $947 \mathrm{~b}$ are missing, which should probably find themselves included after cuarteto 949d. This collection of missing songs may constitute the largest to be missing from the LBA. One or more songs are missing from the Serrana episodes, though it is the section with many of the songs still intact. S1326a makes reference to "aquestos versos" that are never to be seen, though in this case the words may not so much have gone missing as having been left understood. The "mucho cantar" referred to in $1508 \mathrm{~d}$ are missing.

${ }^{6}$ See, for example, G. B. Gybbon-Monypenny, ed., "Introducción biográfica y crítica" in Libro de buen amor by Juan Ruiz, Arcipreste de Hita (Madrid: Castalia, 1988), 7; Óscar Pereira Zazo and Anthony N. Zahareas, eds., in Libro del Arcipreste o de buen amor by Juan Ruiz, Arcipreste de Hita (Madrid: Espasa Calpe, 1994), 14; and Alberto Blecua, ed., "La fecha y el autor" in Libro de buen amor by Juan Ruiz, Arcipreste de Hita (Madrid: Cátedra, 1998), xvii.
} 
from the three remaining Libro de buen amor compilations but rather at the 302 that must have completed the text originally.

Any frustration that the mysterious missing verses may produce could result in some aggravation concerning the flow of the account but no great inability to follow, nor to ascertain, the storyline or plot. This is because the dialog and the narrative verses help to fill in many of the breaches. Also, an additional advantage can be realized by any reader or audience member who may already be familiar with, or who chooses to become familiar with, Pamphilus de amore by Ovid, an underlayment the Archpriest may have counted upon with his audiences. And indeed Juan Ruiz names Ovid directly in the final verses of the tale. The Gayoso text reads thusly:

a doña endrina $\&$ don melon en vno casados son alleganse las conpanas\& las bodas con rrazon si villanja he fecho ay de uos perdon en lo feo de la estoria dize panfilo \& nasón

And the Salamanca manuscript reads:

a doña endrina \& don melon en vno casados son alegranse las con pañas en las bodas con rrazon sy vyllanja he dicho / aya de vos perdon que lo felo de estoria diz panfilo \& nason. ${ }^{7}$

The fact that the episode derives from the Ovidian work does not escape the notice of Elisha Kent Kane, one of the Libro's most popular translators into English, who chooses to address any potential confusion that the missing verses might cause by including the corresponding translated verses from the twelfth-century Latin play. ${ }^{8} \mathrm{He}$ incorporates this for the climactic scene, even if not for the other equally large, but perhaps judged by Kane not quite so compelling, lacuna. The choice made by Kane may be more in harmony with the ethics of translation than it is with those of an edited volume of the Libro de buen amor in the original language. But it is also a choice that may prove instructive in

${ }^{7}$ Stanza 891: Sir Melon then with Lady Sloe was joined with nuptial glory And merrily the twain indulged in jousting amatory, Wherefore, my friends, please pardon me if I've said aught that's whorey Since Pamphilus and Naso wrote the worst part of this story.

${ }^{8}$ Kane, 156-59. 
pursuit of many of those queries concerning what is absent from the account and what Juan Ruiz's sources may have been. The answers to these questions might have less to do with the text and plot and more to do with the poetic performance, the audience reception, and the spectator retention and dissemination of the episode.

It may prove enlightening to note that Kane inserts 13 stanzas of 6 pentameter verses each in order to connect a storyline for which the Archpriest uses 32 cuaderna vía stanzas. The team of Ovid and Kane were able to close the plot loop with 78 verses, as compared to the 128 required, or if not required at least tapped, by Juan Ruiz. (Not wishing to follow the syllabic disproportion too much further, I should still point out that Juan Ruiz's alejandrinos often exceed the two heptasílabo hemistiches pattern. He appears never to employ verses composed of fewer than 7-7, nor greater than $8-8$, but he clearly sees as legitimate and in lyric harmony any combinations of 14,15 , or 16 syllables. ${ }^{9}$ ) If we follow that trajectory a little further we might also observe that the entire Pamphilus de amore consists of 781 Latin hexameter and pentameter verses, while Juan Ruiz composed 1208 alexandrine verses to relate what is essentially the same plot. That reveals metrically a major difference amounting to as much as 9,102 units: 7,810 units used in Pamphilus compared to 16,912 employed in the Libro. That amounts to a difference of just over $46 \%$ less text required by Ovid. ${ }^{10}$

The fact that the plot remains the same for each of these verse representations while the length of the poetic submission diverges as much as it does may beg that we take some medieval uses of poetry into account while engaged in finding the episode's source. It is also the kind

\footnotetext{
${ }^{9}$ In a short metric survey, I started on the first stanza of the episode and then vaulted forward another twenty stanzas and then repeated that process every 20 stanzas until the end of the Don Melón and Doña Endrina story. Stanza 653 possesses one line of 8-8 and two of 7-8; 673 is all 7-7; 693 includes one $8-7 ; 713$ reads $8-8$ for all four lines; 733 is 7-7 throughout; 753's second line is $8-7 ; 773,793,813$, and 833 are all 7-7; 853 reads $8-7,7-8$, $8-8$, and $8-8 ; 873$ counts $7-8,8-8,8-8$, and $8-8$; and the final stanza of our adventure delivers $8-8,8-8,7-7$, and $8-7$. For further metric insight, see the exhaustive metric study executed by Omar Sanz in his doctoral dissertation entitled "Usus scribendi y la cuaderna vía del Libro de buen amor" (Universidad Autónoma de Barcelona, 2012), directed by Francisco Rico.

${ }^{10}$ It should be noted that the "Enxiemplo de la avutarda e de la golondrina" ("The Fable of the Bustard and the Swallow," Elisha Kent Kane translation) is intercalated into this section, stanza 746, and I do not separate the episode because the "enxiemplo" (example) should be considered part of the episode, and it is included in order to illustrate certain virtues of the protagonist.
} 
of scrutiny that may prove instructive concerning our inquiries into what is indeed missing in the Libro version and what served the Archpriest for modeling his account of the matching storyline.

Paul Zumthor speaks about medieval poetry in terms that seem to view textual representations of poetry as either a snapshot of a given performance, the instruction book for a performance, or the script for a reading performance. Consider these observations:

The most pertinent general characteristic of medieval poetry might justly be held to be its dramatic aspect. All through the Middle Ages, with only some exceptions, texts seem to be designed to function theatrically as part of the communication between performer (singer, reciter, or reader) and public. The text literally has a role to play on a stage, and what the public cared most about was that there should be a successful performance of a good role. [...] Even though the oral character of medieval culture ceased to be so clearly defined, perhaps from the twelfth and certainly from the thirteenth century, its poetic forms continued to bear a sort of hereditary trace whose effects persisted at least into the fifteenth century. ${ }^{11}$

Zumthor then compares this dynamic to the present when he states that "for us the text is identified with the book, a material, visual, manufactured object. For most people in the Middle Ages, and indeed throughout most of this long period, the text was an audible and therefore fluid and changeable object." "When Zumthor mentions poetry in relation to its potential users, "singer, reciter, or reader," rather than "audience," he approaches a conceptualization that presses text into the service of the performers, the singers, the reciters, and the readers, in order that those singers, reciters, and readers might serve an audience. The act of making the text public, performing (actually publishing in the medieval sense of the word), was the responsibility of the performer, and while the performance of a singer, a reciter, and a reader have much in common, they do enjoy some significant differences.

The fact that Pamphilus is a comedia and the Libro de buen amor is a narrative calls attention to a disparity in the dynamic investment, the performativity. Actors commonly portray characters with a higher degree

\footnotetext{
${ }^{11}$ Paul Zumthor, Toward a Medieval Poetics, trans. Philip Bennett (Minneapolis and Oxford: University of Minnesota Press, 1992), 18.

${ }^{12}$ Zumthor, 21.
} 
of comprehensible physicality that can reduce the need for supplementary verbal connectivity, while a single performer or a small troupe, like juglares, minstrels, troubadours, or lectors, regularly portray characters with a higher degree of comprehensible vocalized poetry that can condense the requirement for additional theatrical affectations. Both poetic spheres, language/poetry and performance, may proliferate or dwindle in harmony with the dynamics of the structure and method for delivery, something that these textual representations, of Pamphilus and the Libro, may be illustrating. ${ }^{13}$

The two distinct types of poetic works may have caused Juan Ruiz to develop through the language of his poetry much of what Ovid was able to leave to thespian performance. Ovid and Juan Ruiz reach a dynamic division ratio of approximately 32/68, or 68/32, favoring language in the work by the Archpriest and performance in that of Ovid. An example of this phenomenon is visible in the Archpriest's rendering of the Galatea character into his Doña Endrina. In Anthony Zahareas' 1965 study, The Art of Juan Ruiz Archpriest of Hita, the author argues that:

despite some similarities, Galatea provides no adequate model for Endrina; in fact, Endrina's portrait draws much of its characterization from outside the episode related to Pamphilus. Juan Ruiz grafts to the character of the victim a complete rhetorical outline of her physical features (something completely lacking in Galatea) and then refers to them during the episode to create an unusually vivid portrait of her. ${ }^{14}$

Zahareas demonstrates his point impeccably, but seems to forget that no "outline of her physical features" should be required with an actor or an actress on stage whom the whole audience can see and thus "outline" for themselves. Moreover, any such "outline" might have to be altered with each new performer to play the part of Galatea, a circumstance not in force concerning Doña Endrina.

\footnotetext{
${ }^{13}$ This brings to mind John Miles Foley's observation in How to Read an Oral Poem: "Immanent Art shows that Voiced Texts, like Oral Performances, depend on idiomatic cues; the crucial difference is that many of these cues are performative rather than verbal and can be transmitted to textual representation only with difficulty and only approximately" (Urbana and Chicago: University of Illinois Press, 2002), 120.

${ }^{14}$ Anthony Zahareas, The Art of Juan Ruiz Archpriest of Hita (Madrid: Estudios De Literatura Española, 1965), 153.
} 
The simple fact that greater representational exigencies are put upon the performance of the comedia, and upon the language/poetry in the case of the Libro, may communicate still more concerning the culture of Juan Ruiz's poetics. It may also manage to put our poetics perspective to some degree at odds with a philological one concerning the episodes. In Accorsi's article "El Pamphilus de Juan Ruiz," 15 the philologist inserts herself into a polemic that has taken as its aim the determination of whether or not philological erudition can determine which manuscript was referenced, or most likely to have been referenced, by the Archpriest when composing this part of the Libro. She confronts the polemic in medias res by enlisting earlier voices like Pamphilus editors Franz Becker and Lisardo Rubio and Tomás González Rolán, and two primarily Pamphilus/Libro scholars, Jesús Alturo Perucho and Luis Jenaro MacLennan. ${ }^{16}$

Each of these scholars seems to gravitate toward a point on the continuum that privileges the informing connectivity between an individual manuscript, to the exclusion of others, of Pamphilus. What would such a text, a manuscript, have to reveal before it might be demonstrated to be the informing source of the Melón/Endrina tale in the Libro? Did the Archpriest compose at his desk with a manuscript of Pamphilus in front of him, or was a performance of the play the primary text from which Juan Ruiz acquired the Ovidian comedia and proceeded to build his own version of the events and characters, and what Zahareas called "a complete rhetorical outline of [their] physical features"? If Juan Ruiz experienced the Pamphilus in all of its performed glory, then the idea that he also may have availed himself of an auxiliary, or secondary, text in the form of an Ovidian script might prove frustrating to demonstrate until such time as an original copy of the Libro de buen amor is discovered with footnotes and a bibliography. Because, if Juan Ruiz received the text theatrically, that is to say performed, as he and his

\footnotetext{
${ }^{15}$ See Accorsi, p. 1.

${ }^{16}$ See Franz G. Becker, Pamphilus. Prolegomena zum Pamphilus (de amore) undkritische Textausgabe (Ratingen-Kastellaun-Düsseldorf: A. Henn, 1972); Lisardo Rubio Fernández and Tomás González Rolán, Pamphilus De amore (Pánfilo o El arte de amar) (Barcelona: Bosch, D.L., 1977); Jesús Alturo I Perucho, "El manuscrit més antic del Pamphilus, copiat a Barcelona?" Faventia 19 (1997): 65-74; and MacLennan, cited above.
} 
contemporaries absorbed their textuality, his integration of that textuality should not fluctuate appreciably between the two forms of acquisition.

In the event that one were more keenly connected to his reception than the other, I would argue that the performance should have been the more reliable and I would have to disagree with Accorsi's opinion that it was unlikely "that the adaptation could have been made exclusively from memory." 17 Though Juan Ruiz was immersed in letters, he was still a member of the pre-print era and poetics wrote language onto the medieval memory, a process that writing after print would soon begin to usurp and supplant for a variety of selected uses. ${ }^{18} \mathrm{I}$ suspect that Accorsi's dismissal of the probability that the archpriest's memory of Pamphilus de amore performed could have been his primary text may be more informed by Accorsi's modernity, or post-modernity, than by Juan Ruiz's culture. So, I would transpose Accorsi's words and say that I think that the adaptation was probably made primarily from memory and poetic creativity, though it would not be strange that ancillary readings may have contributed, constituting one more source.

To finish, let me say that it is not my intention to diminish the philological studies that have attached themselves to this Pamphilus/Libro association. I find them to be extremely well considered and articulated. I would only shift the vista slightly from one that seeks the manuscript that guided Juan Ruiz, to one that seeks the closest snapshot of the performed texts exploited by the Archpriest.

\section{North Dakota State University}

\footnotetext{
${ }^{17}$ Accorsi, 1.: "No creo que la adaptación pueda haberse hecho exclusivamente de memoria, pero no sería extraño que eventuales reminiscencias de lecturas juveniles hubieran dejado huellas, constituyendo una fuente más." Translated by Carlos Hawley Colón.

${ }^{18}$ See Walter J. Ong, "You know what you can recall: Mnemonics and formulas," in Orality and Literacy: The Technologizing of the Word (London and New York: Methuen, 1982), 33-36.
} 
Bibliography

Accorsi, Federica. "El Pamphilus de Juan Ruiz." Alicante: Biblioteca Virtual Miguel de Cervantes, 2012. https://cvc.cervantes.es/literatura/arcipreste_Hita/02/accorsi.htm

Alturo i Perucho, Jesús. "El manuscrit més antic del Pamphilus, copiat a Barcelona?" Faventia 19, no. 1 (1997): 65-74.

Becker, Franz G. Pamphilus. Prolegomena zum "Pamphilus (de amore)" und kritische Textausgabe. Ratingen-Kastellaun-Düsseldorf: Henn, 1972.

Blecua, Alberto, ed. Libro de buen amor by Juan Ruiz, Arcipreste de Hita. 4th ed. Madrid: Cátedra, 1998.

Foley, John Miles. How to Read an Oral Poem. Urbana and Chicago: University of Illinois Press, 2002.

- The Theory of Oral Composition: History and Methodology. Bloomington: Indiana University Press, 1988.

Gybbon-Monypenny, G. B., ed. Libro de buen amor by Juan Ruiz, Arcipreste de Hita. Madrid: Castalia, 1988.

— - ed. 'Libro De Buen Amor' Studies. London: Grant \& Cutler, 1970.

- Sex, Scandal and Sermon in Fourteenth-Century Spain: Juan Ruiz's Libro De Buen Amor. New York: Palgrave Macmillan, 2008.

Jenaro-MacLennan, Luis. "Sobre el texto del Pamphilus en el Libro de buen amor." Revista de filología española 68 (1988): 143-51.

Kane, Elisha Kent, trans. The Book of Good Love. Newark, Delaware: Juan de la Cuesta, 1933.

Ong, Walter J. Orality and Literacy: The Technologizing of the Word. London and New York: Methuen, 1982. https://doi.org/10.4324/9780203328064

Ovid. Una Comedia Latina Del Siglo XII (El "Liber Panphili"). Reproducción de un Manuscrito Inédito y Versión Castellana. Edited by Adolfo Bonilla Y San Martín. Vol. 70. Madrid: Boletín De La Real Academia De La Historia, 1917.

Pereira Zazo, Oscar, and Anthony N. Zahareas, eds. Libro del Arcipreste o de buen amor by Juan Ruiz, Arcipreste de Hita. Madrid: Espasa Calpe, 1994. 
Rubio Fernández, Lisardo, and Tomás González Rolán. Pamphilus De amore (Pánfilo o El arte de amar). Barcelona: Bosch, 1977.

Ruiz, Juan. Libro de Buen Amor. Texto sinóptico. Edited by Margarita Freixas Alás. Bellaterra: Centro para la Edición de Clásicos Españoles, 2002. CD-Rom edition.

Sanz, Omar. "Usus scribendi y la cuaderna vía del Libro de buen amor. $\mathrm{PhD}$ diss., Universidad Autónoma de Barcelona, 2012.

Vansina, Jan. Oral Tradition: A Study in Historical Methodology. Translated by H. M. Wright. New Brunswick, New Jersey: Aldine Transaction, 2006.

Zahareas, Anthony N. The Art of Juan Ruiz, Archpriest of Hita. Madrid: Estudios De Literatura Española, 1965.

Zumthor, Paul. Oral Poetry: An Introduction. Minneapolis: University of Minnesota Press, 1990. 